\title{
The Remote Causes of Affirmative Action, or School Desegregation in Kansas City, Missouri
}

\author{
Richard A. Epstein $\dagger$
}

\section{Introduction: A Tort Guide to Public Policy}

In jure non remota causa sed proxima spectatur. In law, not the remote but the proximate cause is to be observed. This quotation from Bacon's Maxims is without doubt the origin of the modern tort doctrine of proximate causation, by which we attribute certain harmful consequences to some prior wrougful act. The doctrine is often criticized because the "nearest" cause need not be the exclusive cause or even the dominant one. In spite of these substantive criticisms, Bacon's terminology continues to hold fast to the legal imagination against such blander formulations as "legal cause" or "substantial factor."

Although the language of proximate cause might not capture all the truths about problems of causation, it does capture at least one. There comes a point at which it no longer makes sense to scour the world for remote antecedents of particular harms. The further back one goes, the less the map of causation will look like a river surging toward the sea, and the more it will resemble a delicate network of capillaries meandering toward a common destination, with no dominant beginning or end. Concentrating on the "proximate" identifies the events likely to have had the greatest impact. It is by focusing on these sources that law and administration can exert the greatest control. One might look to see if $A$ made $B$ hit $C$, but one will not conduct, at least within the framework of litigation, a sociological inquiry into all the past influences that could have led the young $A$ to perform an asocial act years later. Thus, while we might peek past the proximate cause, we never travel very far in tort down the road toward remote antecedents, and we are all the better for the truncation of this causal journey.

A quick glance at the Supreme Court's decision last year in Missouri v. Jenkins ${ }^{1}$ (Jenkins III) reveals that no such primciple of

Copyright $\odot 1996$ California Law Review, Inc.

$\dagger$ James Parker Hall Distinguished Service Professor of Law, The University of Chicago. I should like to thank Todd Molz for his valuable research assistance in the preparation of this Article.

1. 115 S. Ct. 2038 (1995). 
prudence reigns in the de jure school desegregation cases still before the Court over forty years after Brown v. Board of Education. ${ }^{2}$ In an age when pressing educational problems are everywhere around us, time has stood still for the federal courts that heroically struggle to eliminate the "last vestiges" of segregation by remedies that have become at once more draconian, unfocused, and futile as the years creak by. The purpose of this short Article is to deplore this remedial trend and to urge the Supreme Court to abandon now the hapless search for legal remedies for the remote causes of a present unpalatable state of affairs. The process of mending-or ending-public education should be conducted by fashioning the best responses we can to the challenges the system now faces, without being deflected by a misguided search for the rectification of past wrongs. ${ }^{3}$

At first it inay appear odd that such a plea should appear in an issue of the California Law Review devoted to the contentious topic of affirmative action. But the linkage between desegregation and affirmative action is quite close. The standard principles of equity preach that for every wrong there ought to be a remedy. Yet by the same token, equity demands that the reinedy be limited to the wrong created. The remedy should impose duties only on the wrongdoer and offer its benefits only to the injured parties, and only for the wrong suffered. Just as it is inappropriate to leave some injuries unredressed, so too is it improper to impose remedies that go beyond the scope of the original wrong. If $S$ refuses to convey Blackacre to $B, B$ 's remedy is against $S$ for specific performance of Blackacre. While interim damages could be added to make up for the time loss, an order to convey Whiteacre along with Blackacre would be condemned as a form of judicial overreaching. Excessive remedies, like inadequate remedies, are to be avoided.

The school desegregation cases are far more anbitious in their scope than an ordinary dispute over nonperformance of a land sale contract, but the same principles apply. A remedy that leaves some portion of the past wrong unredressed is inadequate. A remedy that provides relief for wrongs that have not been committed is excessive. Inadvertent errors are surely par for the course, and if a court is faced with a choice between doing too much and doing too little, it may be forgiven, and perhaps cominended, if it errs on the side of the innocent party. Nevertheless, sometimes proposed remedies are so excessive they cannot be justified as rectification of past wrongs. When we do not have the original wrongdoer or the original victim before the court, and when remedies are imposed on innocent parties for the benefit of other inno-

2. 347 U.S. 483 (1954).

3. For evidence of the decline in educational standards, see Sam Peltzman, The Political Economy of the Decline of American Public Education, 36 J.L. \& EcoN. 331 (1993). 
cent parties, then the judicial apparatus has lost sight of the equitable principles that govern its remedial powers.

In the context of segregation, if the remedy is no longer tailored to acts of past discrimination, it can no longer be justified by any theory of rectification. In deed, but not in word, the remedy begins to reseinble a system of affirmative action-covert and imprecise, to be sure, but affirmative action nonetheless. Just this progression is evident in Jenkins III. The preferences do not run lock-step on racial lines; some whites, as well as some blacks, benefit from the program. But this muddying of the waters is best understood as a halfway house providing refuge from the fierce political and judicial resistance that would accompany a bald and unambiguous affirmative action program. ${ }^{4}$

This backing and filling is not uucommon. The complex scheme of bidding preferences in the Small Business Act, ${ }^{5}$ for example, manifests this same kind of ambivalence. Congress sensed the difficulty in creating a program that simply gives preferences to minorities and women. However, it could not give up on the idea altogether, so it scraped together a compromise that also gives other disadvantaged individuals some, but not quite as much, preference over white nnales. The result is a sprawling and inconclusive Supreme Court decision in Adarand Constructors, Inc. v. Pena, ${ }^{6}$ whose zigs and zags defy easy summarizatiou.

The orders in dispute in Jenkins III have their origin in litigation and not legislation, but they twist and turn like the legislative creations that introduce quasi-affirmative action programs. So desperate are the judges in Kansas City to do something about the situation in public education that they falsely link all present maladies to actions that took place two generations ago. This form of judicial heroism carries with it a hefty price tag, for it is immediately evident that no contemporary defense can be offered for the spending and management decisions in the district court's proposed order. ' The bottom line is that the federal courts have taken control of state and local budgets and are making management decisions in complete disregard of the considerations that would properly be taken into account by a responsible school board.

This Article argues that the remedial orders of the district court are really nothing more than components of a poorly tailored affirmative action program. Part I gives an overview of the lengthy litigation that

4. See, e.g., Hopwood v. Texas, Nos. 94-50569, 94-50664, 1996 WL 120235, at *26 (5th Cir. Mar. 18, 1996) (restricting the use of racial preferences in the admissions program of the University of Texas School of Law).

5. 15 U.S.C. $\S 831-656$ (1994).

6. 115 S. Ct. 2097 (1995).

7. For the decisions below, see Jenkins v. Missouri, 13 F.3d 1170 (8th Cir. 1993); Jenkins v. Missouri, 11 F.3d 755 (8th Cir. 1993). 
has led to this latest Supreme Court decision. Part II briefly demonstrates the sharp differences between judicial management and the forward-looking administration of public schools. It does so by contrasting the work of a district court judge in fashioning a "remedial" school desegregation plan with that of a hypothetical private consultant, hired to improve school performance in one district without hurting schools elsewhere in the state. Part III then examines the four components of the district court's remedial plan in Jenkins. At the most fundamental level, I argue that the entire remedial enterprise is flawed because it is no longer possible to identify either victims or wrongdoers. Because the Supreme Court remains willing to tolerate such a loose connection between today's remedy and yesterday's remote wrong, its response in Jenkins III was too timid to curb the endless litigation and remedial excess that has arisen in the afterglow of Brown. Finally, in Part IV, I argue that the "remedial" plan at issue in the Jenkins litigation is really no more than a thinly veiled and unjustifiable affirmative action program.

The original draft of this article was written without the benefit of John Choon Yoo's excellent contribution to this symposium, ${ }^{8}$ which also critiques the decision in Jenkins III on the ground that the courts have placed far too much reliance on the structural injunction to correct the ostensible sins that are found, not only in the school desegregation cases, but also in such areas as prison reform, mental health, and housing. His arguments dovetail closely with my own, but differ from them in focus and emphasis. My dominant concern is less with the inherent power of courts of equity to enter structural decrees, and more with the advisability of using such decrees to remedy wrongs whose active commission ceased a long time ago. My analysis tracks that of Yoo in stressing the difficulties of finding the status quo ante to which some

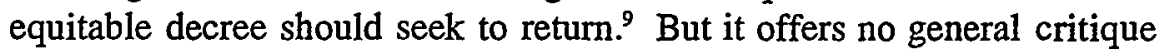
of structural injunctions as they apply in other contexts.

It is possible, therefore, to defend the general use of structural injunctions for recent or ongoing wrongs, while deploring their use-as well as the use of damage actions or other forms of remedial relief-to handle the sins of past generations. I avoid taking a position on structural injunctions generally, or on their relationship to federalism and the Tenth Amendment, the scope of the judicial power under Article III, or the doctrine of separation of power-the issues that occupy so much of Yoo's paper..$^{10}$ Rather, I have confined my criticism

8. John Choon Yoo, Who Measures the Chancellor's Foot?: The Inherent Remedial Authority of the Federal Courts, 84 CALIF. L. REv. 1121 (1996).

9. Id. at 1137-41.

10. Id. at 1141-66. 
to use of the structural injunction in the context of de jure segregation that ceased when Brown became the law. Stated otherwise, my difficulties with the injunction are substantive, not structural, for I would be as inuch opposed to its use in this context if it were implemented by the Missouri state courts as by the Supreme Court. But I do not think it just a matter of comcidence that the Jenkins saga has been staged from first to last in the federal courts.

\section{A Longish CASE HISTORY}

In order to put Jenkins III in perspective, it is necessary to recall a few of the major benchmarks of American history. As Justice Ginsburg notes, the black codes were imtroduced in the early 1700s." The Constitution, with the Three-Fifths Clause, was adopted in 1787. The Civil War ended in 1865. The Reconstruction Aunendments were adopted in 1868. Reconstruction itself ended in 1877, and some semblance of integration was preserved in the South until the 1890 s, when populist radicals were able to wrest control of local political bodies and impose Jin Crow. Segregation became the norm, with segregated trams and buses, anti-miscegenation laws, and of course, segregated schools. The entire program was held to be within the scope of the state police power in Plessy v. Ferguson, ${ }^{12}$ which was decided in 1896.

The scope of segregation, especially in education, was not confined to public schools; nor was it confined to the South. Many border and northern states maintained some form of segregation until the end of World War II. Thus, it must never be forgotten that the first of the named defendants in Brown v. Board of Education was the Board of Education of Topeka, Kansas. Without question, Kansas City, Missouri segregated schools by race until 1954, when the system was disbanded in the wake of Brown. Some ten years later Congress passed the Civil Rights Act of 1964. ${ }^{13}$ This epic lawsuit began in 1977, when the Kansas City, Missouri School District (KCMSD), the school board and the children of two school board members-no coincidence here!-brought suit against the State of Missouri and against surrounding suburban school districts (SSDs), seeking relief from the lingering effects of racial segregation. ${ }^{14}$

The Jenkins litigation began twenty-three years after Brown and has continued for nineteen years inore. It shows no signs of letting up,

\footnotetext{
11. Jenkins III, 115 S. Ct. at 2091 (Ginsburg, J., dissenting).

12. 163 U.S. 537 (1896).

13. 42 U.S.C. $\$ \S 2000$ a to $2000 \mathrm{~h}-6$ (1994).

14. See Missouri v. Jenkins, 495 U.S. 33 (1990) (Jenkins II); Missouri v. Jenkins, 491 U.S. 274 (1989) (Jenkins I).
} 
for in Jenkins III the Supreme Court remanded the case for further consideration with strict instructions as to the permissible scope of possible remedies. The prior procedural history of the case can only be described as tortured: ${ }^{15}$ the initial trial lasted some seven and one-half months, and resulted in a verdict that dismissed all claims against the suburban defendants and the federal government. However, the State of Missouri was found to be in violation of Brown insofar as it had segregated its students before 1954, and had thereafter taken tepid and insufficient steps to eliminate the vestiges of segregation. ${ }^{16}$

One year later, the district court issued its remedial order, whose stated goal was the "elimination of all vestiges of state imposed segregation."17 The district court noted the high concentration of black students $(68.3 \%)$ in the KCMSD, and that twenty-five of its sixty-eight schools had black enrollments of over $90 \%$. The district court further determined that the harm suffered as a result of the original breach of duty was a reduction in overall student achievement levels withm the KCMSD. However, it never attempted to explain what portion of the below-level.achievement was attributable to prior segregation, and what portion to other causes of more recent origin. Consistent with its view of the case, the district court then ordered an extensive remedial educational program with the goal of improving every area of operations withm the KCMSD. Its ultimate aspiration was to restore the KCMSD to a AAA classification, the highest awarded by Missouri's State Board of Education. The district court ordered a reduction in class size, full-day kindergarten and expanded summer school, before- and after-school tutoring, and an early childhood development program. By any standard measurement, the resources poured into the KCMSD far exceeded those necessary to meet the AAA standard. They also exceeded by far the level of resources available in the wealthiest suburban school district in the state. The cumulative capital budget for the KCMSD was $\$ 260$ million as of 1990 , and rose, as of the date of Jenkins III, to over $\$ 540$ million. ${ }^{18}$ The per-pupil expenditures, excluding these capital costs, were $\$ 9,412$ per pupil, the price of a hefty private school tuition, while the comparable figures for the SSDs varied from $\$ 2,854$ to $\$ 5,956 .^{19}$

The district court did not confine its remedial labors to educational programs, which almost by definition could not alter the racial composition of the KCMSD. Since no suburban school districts were in violation of their constitutional obligations, the Supreme Court's key prior

15. For the Court's summary of the history, see Jenkins III, 115 S. Ct. at 2042-45.

16. Jenkins v. Missouri, 593 F. Supp. 1485, 1505-06 (W.D. Mo. 1984).

17. Jenkins v. Missouri, 639 F. Supp. 19, 23 (W.D. Mo. 1985), aff d, 807 F.2d 657 (8th Cir. 1986).

18. Jenkins III, $115 \mathrm{~S}$. Ct. at 2044.

19. Id. at 2054. 
decision in Milliken v. Bradley ${ }^{20}$ (Milliken I) blocked the district court from conscripting them into participation in an interdistrict remedy. To skirt the prohibitions of Milliken I, the district court proposed building magnet schools inside the city, in order to attract white students from the suburbs and produce racial balance. In addition, the district court ordered an intensive program of capital improvements aimed at making the schools' physical environinent more appealing to suburban students-in other words, to improve the "desegregative attractiveness" of the KCMSD. The original plan called for the creation of a veritable Land of Oz:

high schools in which every classroom will have air conditioning, an alarm system, and 15 microcomputers; a 2,000-square-foot planetarium; green houses and vivariums; a 25-acre farm with an air-conditioned meeting room for 104 people; a Model United Nations wired for language translation; broadcast capable radio and television studios with an editing and animation lab; a temperature controlled art gallery; movie editing and screening rooms; a 3,500-square-foot dust-free diesel mechanics room; 1,875 -square-foot elementary school animal rooms for use in a zoo project; swimming pools; and numerous other facilities. ${ }^{21}$

Finally, the plan called for increases in teachers' salaries, with the purpose of attracting and keeping the best faculty and thereby further promoting the schools' "desegregative attractiveness."

The district court adopted this inulti-pronged remedy on the ground that the KCMSD had failed to desegregate its schools after Brown. As long as some vestige of past discrimination remained discernible, the Court would reserve full equitable powers and the management of Kansas City's schools would be essentially backwardlooking and remedial in nature. Only when the KCMSD came into full compliance would the focus on past wrongs in the making of management decisions for the school district come to an end. ${ }^{22}$

In Jenkins III, the Supreine Court rebuffed the district court in three ways. First, it held that the creation of magnet schools in order to attract suburban students was not an appropriate remedy for past segregation within the KCMSD. The only wrongs that the district court identified took place inside the KCMSD, and there was no showing that the segregative effects of these violations had influenced official patterns of

20. 418 U.S. $717,748-53$ (1974).

21. Jenkins III, 115 S. Ct at 2044-45 (quoting Jenkins II, 495 U.S. at 77 (Kennedy, J., concurring)).

22. See Freeman v. Pitts, 503 U.S. 467, 491 (1992) (setting out the factors under which a court's supervision could end). But the emphasis on full compliance and good faith commitment to the enforcement of the Court's decree means that there is never any fixed termination to post-Brown remedial proceedings. 
behavior in other districts. Just as the Court could not enlist the SSDs in an integration remedy, so it could not cure iutra-KCMSD violations by luring suburban students into the district. Next, the Supreme Court held that the across-the-board salary increases were also inappropriate; they, too, were implemented to promote "desegregative attractiveness," and thus were not remedies tied to the commission of a localized wrong. And finally, the Supreme Court rejected the district court's standard of compliance: the Court could not require that the KCMSD's students test at or above national norms as the prerequisite for terminating judicial supervision..$^{23}$

\section{III}

\section{LAW VeRsus MaNAGEMENT}

Jenkins III revealed the deep intellectual and ideological splits insicle the Supreme Court. The heated skirmishes among the justices were motivated by strong differences in attitudes among the justices toward remedial relief for remote wrongs. The majority of five was tired of once again having to review a case that had dragged on for eighteen years without conclusion. While fatigue was the dominant impulse on the Court, Justice Souter iu dissent expressed a different brand of impatience: he had had enough of what he perceived as the nonstop bad faith of the KCMSD from the outset of the litigation. ${ }^{24}$

For all its passion, however, this dispute misses the mark by contimuing to focus ou the kind of remedies the district court should have adopted. It deals with midcourse corrections, not fundamental changes in direction. In this short essay, I want to sidestep this clebate and pose a more dramatic question: why countenance any continuing remedies at all? In my view, it is high time to call a halt to costly and unproductive judicial efforts to rectify remote injustices. Those efforts have failed by any measure that one could bring to bear on them. The tine has come to focus solely on the future and to curb the reinedial exuberance of the federal courts. Throughout this litigation, the district court has arrogated the power to initiate government action, irrespective of any collateral social and financial consequences. It is time to stop it.

In making this plea, I do not rely on some categorical imperative that admits of the necessity of judicial restraint. The whole debate between activism and restraint does little to decide concrete cases litigated under specific clauses of the Constitution. These doctriues create, at most, only a weak presumption for courts charged with passing on the

23. Jenkins $I I I, 115 \mathrm{~S}$. Ct. at 2055-56.

24. Id. at 2074 (Souter, J., dissenting) ("After Brown, neither the State nor the KCMSD moved to dismantle this system of separate education 'root and branch' despite their affirmative obligation to do that under the Constitution.") (citations omitted). 
constitutionality of legislative actions. However, even the extensive judicial intervention that I champion on First and Fifth Amendment matters never requires, or even allows, the Court to initiate government action. Protecting freedom of speech requires only that the courts nullify legislative initiatives that limit speech. Similarly, extensive judicial oversight of takings should prevent some government misadventures from getting off the ground. A taking may be barred because it is not made for public use, or enjoined until the compensation owing is paid; however, even the most aggressive reading of the Takings Clause does not authorize courts to order the legislature to condemn this parcel of land for a post office and that one for a fort. Initiating government action is entrusted exclusively to the legislature. The desegregation cases thus undertake what even the most aggressive advocates of speech and property rights never dare contemplate. Post-Brown jurisprudence ignores the limits on what should go into a court's equitable tool-kit; it equips the judiciary with a power of initiation and management that is ill-suited to its institutional capabilities and that ultimately leads to counterproductive social results. Running public schools is not a job for the federal courts.

To see the powerful contrast between retrospective judicial control and effective remedial administration, suppose the original Jenkins lawsuit had never been filed, but the KCMSD still sought to improve the lackluster performance of its schools. In order to achieve this goal, it hires you as its consultant and charges you with improving school performance in Kansas City, without hurting too much schools elsewhere in the state. Your mission is not to mull over the past, but to set a responsible course for the future. This charge first recognizes the primary educational mission in Kansas City, but also the interconnection between the KCMSD and other school districts in the state. The basic state-wide budget constraint cannot be wished away: money spent in one locale cannot be spent in another. Public officials cannot tap any hidden cornucopia to fund their most treasured projects. Like the rest of us, they live in a world of scarcity and constraint.

How would you respond to this plum assignment? Surely you would familiarize yourself with the history, operations, and resources of the KCMSD. What is the current racial composition of its student body and faculty? How did it get that way? What programs have succeeded? Which have failed? How does recruitment take place? What could be done to improve it? What, if anything, is the correlation between educational investment and achievement? How, if at all, could parents play a role in school functions? What response, if any, has been taken or should be taken toward union demands? The menu of items is long. 
Your aim would be to devise a program that makes incremental but lasting improvements in the operation of the system.

What is striking, in contrast to the judicial approach, is the relative weight you would attach to recent and remote events. Of course, distant causes are not irrelevant, and immediate ones are not decisive; your task would not require you to proceed in accordance with Sir Francis Bacon's maxim on proximate causation. Sound management principles, however, would lead you to weigh immediate causes more heavily than remote ones. Quite simply, recent events are more likely to have a potent impact on the current situation. Events surrounding 1954-to pick a date not quite at random-are unlikely to explain much about what should be done here and now. Stated bluntly, you would not find the key to the KCMSD's current dilemmas in the misdeeds of the dead, defunct, and departed of two generations ago. As a consultant, you would trade one cost against another, one benefit against another, and then make marginal adjustınents in system operations. You would consider a set of well-thought-out hunches and try to make matters better at a reasonable cost. Unlike a desegregation court, you would not adhere to one fixed point before which everything else must yield. Proper management of a school district is a hit-or-miss business, with no single controlling objective and no single dominant constraint.

III

WHAT REMEDIES?

Such forward-looking management highlights four remedial inconsistencies that quite literally juinp off the pages of Jenkins III. The first is the unattainable ideal of perfect rectification of past wrongs for which the desegregation courts strive. The second is the inpossibility of fashioning remedies when both victims and wrongdoers have long since parted froin the scene. The third is the Supreme Court's response to the outsized salary increases the district court ordered for KCMSD teachers. The fourth is Jenkins III's rejection of national norms of student performance as a benchinark for determining when the vestiges of segregation have been eliminated within the KCMSD. Each of these issues brings into question the "remedial" nature of the district court's actions. The Supreme Court's treatment of the last two issues was far better than its treatinent of the first two because it brought to them a skepticism which the entire Jenkins venture deserves. As will be seen, however, the Court's performance would improve markedly across the board if it dislodged the district court from its managerial perch. 


\section{A. The False Hope of Perfect Rectification}

After this brief description, it is useful to recall that the long-lost objective of the original lawsuit was to undo the last vestiges of segregation. The district court's goal is not to restore the system to the position that it was in forty years ago, but rather to create what would exist today had the original wrongs never been committed. To use the Supreme Court's own words, a desegregation remedy "is necessarily designed, as all remedies are, to restore the victims of discriminatory conduct to the position they would have occupied in the absence of such conduct."2s The ideal is rectification. The remedy is an effort to undo the status quo ante even though time has marched on inexorably for two generations. For several reasons, this expectation standard is the wrong way to think about the problem.

First, the above passage implies that the law of remedies for even the most sprawling and complicated of public disputes takes its cue from the private law of remedies. The Court's standard is the expectation measure of damages, which seeks to place the innocent plaintiff in exactly the same position she would have enjoyed had the defendant performed his promises to the letter. While this standard is invoked as a kind of necessary truth, the limitations that apply to it in the private law context are ignored. One common limitation is that no coercive remedy may be imposed when it has adverse consequences on third parties. For example, specific performance is not ordered for a contract to buy or sell real estate if it would destroy a third party's lien. Jenkins' ambitious equitable interventions are shot through with adverse consequences for innocent persons. Third parties outside the district are forced to contribute to the court order's support, while innocents within the district are inconvenienced by its command. Indeed, virtually the entire burden of the district court's remedy falls on parties in no way connected to the original wrong. The protection of third parties has been disregarded by the peculiar version of equity practiced in the desegregation cases.

A similar fate has befallen the traditional understanding that it is not always possible to put the innocent plaimtiff back in the position she would have enjoyed absent the breach. The formal ideal of perfect rectification requires one to reconstruct the past out of whole cloth and is often recognized as unattainable im ordinary contract disputes. ${ }^{26}$ Parties frequently substitute liquidated damages provisions for expectation

25. Id. at 2048 (quoting Milliken I, 418 U.S. at 746).

26. The leading statement of the standard view is found in L.L. Fuller \& William R. Perdue, Jr., The Reliance Interest in Contract Damages, 46 YALE LJ. 52 (1936). For my own criticism, see Richard A. Epstein, Beyond Foreseeability: Consequential Damages in the Law of Contract, $18 \mathrm{~J}$. LEGAL STUD. 105 (1989). 
damages to obviate the need for reconstructing "what might have been," even on a small compass. Courts also recognize that speculative damages are often simply not recoverable. Events need not follow just one course in the absence of a breach; other decisions could intervene, and other contracts could be breached. Just as today's occurrence cannot be traced to a single wrong of years ago, so a single scenario cannot describe all that may have flowed from a determinate past wrong. When calculating "what would have been" becomes too speculative, contract doctrine eschews the expectation standard in favor of reliance and restitution damages. The strong legal preference for avoiding speculative damages has been abandoned in the desegregation cases.

The Court's ideal of perfect restoration also suggests that specific performance should be the remedy of choice, as damages never quite get the job done. In the private law of remedies, other considerations often intervene, including the ability of a court to supervise the remedies it imposes. For example, speciflc performance may be available for failure to convey land to which a defendant has clear title: once the deed is delivered, the court's work is done. But this remedy falters noticeably in the employment context, where the continuous task of supervision requires more intensive judicial monitoring. Rather than trying to make hostile parties work together, a common law court will usually accept a parting of the ways as the better solution. Damages-often liquidated as a multiple of salary, for example, one month's pay for each year served-give a superior remedy that obviates the need for daily intrusions into the workplace. Yet employment disputes are small potatoes compared to the endless system-wide problems of supervision created by judicial management of a major school district. The remedies in Jenkins III go far beyond those imposed in private disputes. Unfortunately, the Supreme Court's statement as to the restorative function of all remedies captures an unattainable ideal, not a plausible result.

One reason for the Court's error is that in its pursuit of hopeless ideals it has forgotten that any sensible remedy is effectively constrained by the principle of diminishing marginal utility. Desegregation cases are not exempt from this rule. The first corrective steps after Brown $v$. Board of Education were easy to implement: terminate the system of explicit segregation and move to residence-based school districts. These two steps could not correct all injustices, but what they did accomplish was important and lasting progress, achieved cheaply and effectively. However, the further down the remedial trail one moves, the greater the risk that the next specific remedy will be under- or over-inclusive. Jenkins' effort to avoid the first error, moving too slowly on desegregation, carries with it the usual consequence: excessive remedial action. Once official segregation has been uprooted, further remedies necessar- 
ily veer toward over-inclusion. The only way to ferret out the last vestiges of segregation is to repudiate many practices that involve no discrimination at all. In a sprawling desegregation suit, no court can direct its remedial laser beam to a clearly defined set of past wrongs. The remedies chosen respond not only to probleins attributable to past segregation, but also to the structural, administrative, parental, and neighborhood failures of the last forty years. The longer the gap between now and the identified wrong, the lower the returns to continued judicial intervention and the greater the risk that any remedy will be excessive.

\section{B. Neither Victims nor Wrongdoers}

The ordinary tort action presupposes that a suit is brought by the victim of a wrong against the wrongdoer, but in Jenkins III no such linkage between the parties can be found. Starting with the victims' side, the Court needs to be able to identify the "victims" protected by a desegregation order. But while the categories of victims can be stated fairly broadly, almost none of the current beneficiaries of the plan fall into even the most capacious definition of the injured class. The obvious victims of past segregation are the children who were educated in segregated schools. Secondary victims might mclude their families. Finally, victins just might include any descendants of these individuals whose own life chances were reduced by the lower incomes of their parents.

Unfortunately, the program in Jenkins III targets a different class of persons, namely all families whose children attend school in Kansas City today. That class of persons has some overlap with the families prejudiced forty years ago, but surely not much. The most obvious difference is that the percentage of black students in Kansas City schools in 1954 was under twenty percent, while in 1995 it came close to seventy percent. Much of this difference in racial composition comes from inmigration that, far from being the consequence of early official discrimination, is a response to the lavish programs and facilities offered to induce individuals of all races to move into the district. Why these outsiders should receive largesse for unrelated wrongs committed to other persons long dead and gone is anyone's guess. The Court defines victims by location and by race. These designations, however, carry with them no independent moral weight; they must serve as proxies for some tangible harm from wrongful state practices. Yet black families who moved to Kansas City in 1990 are hardly the victims of wrongful acts directed toward other residents over thirty years before.

The Court is no better at identifying the putative wrongdoers. It never explains why any duty to rectify runs toward the white citizens of today's Kansas City, who are no more responsible for past segregation 
in the district than the white and black citizens elsewhere in the state who are asked to foot the bill. Any continuity of interest between the group of past wrongdoers and the present defendants is wholly lacking. The only reason for holding the present parties accountable for past segregation is that they are conveniently available when the actual wrongdoers are not. It is not as though earlier victims assigned some imaginary set of remedial rights to persons who moved into the district years after they left. Similarly, it is not as though present shareholders of a corporation are being asked to answer for wrongs committed before they purchased their shares. There is, in short, no glue to bind today's citizens to yesterday's wrong.

Justice O'Connor blinked just a bit when she acknowledged that the remedial order for the KCMSD conferred benefits on "some who did not suffer under-and, indeed, may have even profited from-past segregation." 27 Shrugging the point off, she gamely continued by stating that "[ $t]$ here is no categorical constitutional prohibition on nonvictims enjoying the collateral, incidental benefits of a remedial plan designed 'to restore the victims of discriminatory conduct to the position they would have occupied in the absence of such conduct." the issue of spillover effects is far more acute than this passage suggests. This is not a case where recovery by victims necessitated some relief to persons outside the target class. On the contrary, all of the victims have graduated, and most of their descendants have scattered to the four winds. The spillover effects of this plan are not collateral. Aid to nonvictims is the only thing that the Court's remedy really accomplishes.

An inquiry into the identity of the victims and wrongdoers also calls into question the basic structure of the Court's distinction between inter- and intra-district remedies. For the Court, this line proves durable because the wrongs committed inside the district do not justify burdening those outside of it with an integration remedy. ${ }^{29}$ This distinction would make sense if the Court could explain why the remedial harms should be visited on white families who live within the KCMSD. It cannot. The same reasoning that bars interdistrict relief for an intradistrict violation-that remedial burdens should be imposed only on those persons involved in the original harm-should also bar the intradistrict remedy of Jenkins III.

It is for this reason that we should reject the different spin that Justice Souter places on the observation that it is no longer possible to determine whether the white flight from Kansas City is attributable to past

27. Jenkins III, 115 S. Ct. at 2060 (O'Connor, J., concurring).

28. Id. (quoting Milliken I, 418 U.S. at 746).

29. Id. at 2048-54. 
segregation or the current efforts at integration..$^{30} \mathrm{He}$ is justified in observing that the inability to disentangle the remote causes of the present situation renders unworkable the traditional causal inquiries. But he then jumps in the wrong direction by urging the expansion of judicial receivership, when it is in fact imperative to scuttle the entire futile effort at judicial management.

In rejecting Justice Souter's position, the Court thus makes a good start, excluding from the district court's remedial web the extra-district parties whose connection to the harm is too remote. Unfortunately, it stops short by drawing an arbitrary distinction between those individuals who live inside the district and those who live outside its borders. The dissent inay have thought that the lack of a relevant distinction justified imposing duties on both. The better course of action is to impose those remedies on neither.

Systematically viewed, the vice in this case is not that resources were spent to lure students into the KCMSD from regions that did not practice discrimination. Rather, it lies in the idea that any reference should be made to the wrongs of 1954 in order to answer the question of how educational resources should be allocated today. The Court's position may look conservative in comparison to the dissent's, which sees no harm in inter-district magnets under the Milliken decisions so long as no coercion is imposed on outsiders. ${ }^{31}$ But the Court's position does not bring this lawsuit to an end: it only sends it back for yet another round of litigation below, where once again the wrong ends will be pursued by the wrong techniques.

We have long passed the time when corrections at an institutional level bear any relationship to the commission of any wrong to any individual victim. The local entities are no longer an effective proxy for the individuals who were benefited or burdened by past violations. The Court's reasoning retains some plausibility only because it refuses to pierce the inunicipal veil to see what persons are actually hurt and what persons are helped by its actions. Statements about the welfare of corporations and partnerships are necessarily statements about the welfare of their members. The same methodological caveat also applies to local governments: when a court directs its firepower agamst an organization, it is in fact acting against those who are presently its members. Far from having a fixed membership, however, local entities have permeable boundaries and migratory populations. The residents of a school district today are not the heirs or assigns of the people who lived there forty years ago. Thus, the minimum conditions of a theory

30. Id. at 2084-87 (Souter, J., dissenting).

31. Id. at 2088-89 (Souter, J., dissenting). 
of corrective justice are not satisfied, even if desegregation remedies are limited to the place-not the persons-where the wrong was committed.

\section{More Money for What End?}

The Court's performance improved markedly when it worked itself into a more skeptical frame of mind. In particular, it did far better in questioning why there should be greater teacher salary increases in the KCMSD than elsewhere in the state. I can think of no good reason. It is, of course, no accident that the city teachers' union was strongly in favor of the raises. ${ }^{32}$ An increase in teachers' salaries elevates the wages of existing teachers from competitive to monopoly rates, or, more precisely, from relatively competitive to more monopolistic rates, without any improvement in overall teachmg performance within the district. Any correlation between teachers' salaries and student performance is tenuous at best. What may well be needed is the aggressive recruitment of good teachers, a measure that is very likely blocked by a union seniority system that protects teachers with long years of service, while keeping out newer teachers who might actually make a difference. If forced to choose between a desegregation remedy that banned the union and one that raised the wages of its members, I would without hesitation pick the former over the latter. Why an increase in salary to present teachers rectifies the wrongs to a past generation of students is anyone's guess.

The wage increases go only towards collateral purposes. The lower court thought increased salaries would prevent white-flight, but the Supreme Court held that preventing white-fiight was not a legitimate object of the decree. The salary increases could also be justified as a response to current disamenities in teaching in inner-city schools with predominantly black populations. Those difficult and perhaps dangerous circumstances could easily require some form of a wage premium. Such a premium, however, would bear no relationship to the prior wrong. Rather, the need is created by the breakdown of discipline in modern education, a problem that postdates the fall of segregation and has its origins in the breakdown of the family and in the increasingly percussive nature of popular culture, or so one could argue. The more time that passes, the more likely it becomes that teachers' salaries are responding to forces that did not surface prior to Brown. The need for the wage imcrement may be strong, but it can hardly be traced to the wrong supposedly being remedied. And for all we know, the needs

32. Id. at 2046 (noting the efforts of the American Federation of Teachers (AFT) to obtain the raises and bypass the collective bargaining process). It is interesting that none of the proposed remedies would limit the power of the AFT in order to strengthen the ability of the system to serve students' needs. 
could be as acute in some regions of St. Louis as they are in Kansas City. But the proper response, again, is not to insist that the remedy be narrowly tailored to distant and increasingly irrelevant wrongs. ${ }^{33}$ Rather, it is to jettison the entire process of remedial litigation, and allow management of the schools to be frankly tailored to current needs.

\section{Perpetual Noncompliance}

The constant mantra of Jenkins III is that judicial supervision is required until the last vestiges of segregation are rooted out from the system. Stating the proposition in this way speaks volumes about the riskiness of desegregation litigation. Directing the court's remedial machinery at 1954 guarantees that problems of multiple causation will only grow more acute with the passage of time. As the violation recedes into the past, other phenomena start to contribute more substantially to the KCMSD's desperate condition. However, as long as some fraction of the problem is attributable to the remote wrongs, then the full set of judicial sanctions remains in place. To a cynic, the direction in which these sanctions lead is unmistakable. If the last vestiges of segregation have not been removed in 40 years, why suppose they will be removed in 100 years? The attenuated theories of causation that have allowed the lawsuit to travel thus far have not exhausted their power. If these weak links between past wrongs and present conditions are adequate today, when will the court ever be willing to withdraw from its supervisory role? The upshot is that, having once been segregated, a school district is always subject to judicial supervision.

Stated in this gross form, the outcome was not acceptable even to the district court. The standard that it ultimately adopted recognized the formal possibility that supervision could end, but at the same time made it highly unlikely that this desirable outcome could ever be achieved. More concretely, the district court held that the effects of past segregation were not eliminated, and thus remedial intervention would continue, as long as student achievement levels were still "at or below national norms at many grade levels." ${ }^{34}$ The introduction of this benchmark into the remedial calculus once again demonstrates the perils of an unfettered definition of proximate causation. The most obvious point is that all students in KCMSD were not victims of segregation, so their test scores are not evidence of a continuing harm even under a generous test of remediation. But even were one to assume that all students were victims, the district court established the wrong standard. The relevant control group is not all students in the United States, but rather those

33. See id. at 2063 (Thomas, J., concurring) ("In order for a 'vestige' to supply the ground for an exercise of remedial authority, it must be clearly traceable to the dual school system.").

34. Id. at 2055. 
who work under conditions that approximate those in Kansas City, absent the past history of segregation. The court's benchmark should be inner-city schools with predominantly black populations without a history of de jure segregation. By that standard, parity in Kansas City may have been achieved years ago.

But the remedial investments are far more relevant for another reason. Let us suppose that parity by any definition is not achieved. That failure tells us far more about the impact of additional educational expenditures than it does about the lingering influence of past discrimination within the KCMSD. If those achievement levels continue to lag behind, then far from increasing expenditures, perhaps one should ask whether they should be cut back so that money could be released to other projects where it will yield a greater rate of return. Here the Supreme Court rightly said that the district court had placed far too much emphasis on national norms in evaluating student achievement. Chief Justice Rehnquist held that "the District Court should sharply limit, if not dispense with, its reliance on this factor."35 From a practical point of view that conclusion surely makes good sense, for it is highly debatable whether the KCMSD will ever achieve test parity. But once again the response was too tepid. Why keep the door slightly ajar when the factor could be dispensed with entirely? More importantly, the inability to articulate standards for deciding when the remedial stage of desegregation litigation is over should warn us off this approach altogether. Judicial supervision without a benchmark for returning to business as usual should never be adopted in the first place. The Jenkins litigation's remedial stage should have ended forthwith.

IV

\section{Affirmative Action IN Disguise}

The basic point of this paper is that the desegregation cases have long since passed the point where they can usefully be described as remedial. Efforts to limit the nature and kinds of remedies are commendable insofar as they curb the imaginations of lower courts, but they are only half measures relative to the appropriate response. Reconstruction lasted only twelve years, and then ended. Forty-one years after Brown the Supreme Court should pull the plug on desegregation litigation and seek to do the best it can for present students. Some decisive measures should be taken to dampen the finger-pointing and harm-creation that mevitably arise once remedial action has been permitted on so intrusive a level.

35. Id. (citations omitted). 
There is another way to look at this problem. Earlier I emphasized that any consultant asked to set a course for the KCMSD would think about current problems relative to current resources. On those terms, no one could defend the huge amount of resources poured into one district at the expense of all others within the state. The official justification for the expenditure imbalance is the remedial fig-leaf kept alive by the Court, and once that fig-leaf is removed, the extra expenditures must stand or fall on their own merits. It is quite clear that they are all made on a race-conscious basis. It is quite clear that they reduce the total impact of the educational dollar with their skewed impact. If this entire enterprise cannot sensibly be described as remedial, then it has only cne naine left. It is a form of affirmative action. Can it be justified on those grounds?

One is hard pressed to explain why such a distribution of benefits and costs makes sense in this context. The allocations here are not inade according to wealth, and in an odd sense they are only imperfectly made according to race, for there are whites within the KCMSD who benefit from the program and blacks outside the district who are hurt by it. As with all affirmative action programs, the fit between means and ends is far from perfect, and there is always an effort to cover one's tracks by multiplying purposes and skewing eligibility so that the "naked" form of the practice no longer exists. But while the district court's affirmative action program is embedded in an outgrown remedial context, it shares all the defects of such programs. Because the basic design is covert, the size and scope of the venture can easily outgrow its usefulness. As is evident in the KCMSD, the size of the budget is determined by non-political sources, and the returns promised from these coerced expenditures are speculative at best. I am no fan of the political process in general, but here, relative to interventionist judges, the citizens of Missouri and their elected officials will do a much better job of allocating educational resources than the bench or the bar.

\section{ConCLUSION}

In saying this, I do not mean to depart from my view that strong judicial intervention is necessary to keep legislatures from running amok ${ }^{36}$ I have little patience for the multiple forms of expropriation that pass under the name of regnlation, and I still believe that courts should keep legislatures in line. But that view never comprehended the creation of the taxing power in the courts, nor the forced expansion of a board of education by judicial decree. Rather, the judicial function should be to insure that all governmental bodies do not overstep their

36. See generally Richard A. Epstein, Takings: Private Property and the Power of EMinent Domain (1985). 
limits and engage in extensive acts of redistribution whose overall effect is to diminish the stock of social wealth. The norms, therefore, that should be invoked are substantive, with an eye toward reducing the power and scope of government in all branches, judicial as well as legislative. If large government for redistribution is bad when created by legislatures and blessed by courts, it is only worse when created by conrts and imposed on legislatures. The question of how to allocate educational funds is vexing enough if we only concentrate on the future, taking into account the need to contain present discrimination in the public weal. It is a mistake of constitutional proportions to allow remote wrongs to justify the unprincipled forms of affirmative action embedded in an endless web of judicial remediation. It is time to ditch the courts in the desegregation cases and get on with the future. 